\title{
Studies of the floral biology of neotropical Nymphaeaceae. 3
}

\author{
Ghillean T. Prance (") \\ Anthony B. Anderson $(\stackrel{*}{*})$
}

\begin{abstract}
A field study of the floral biology of two species of Nymphaea (Nymphaeaceae) was made. N. rudgeana G.F.W. Meyer, a night flowering species, was studied around Manaus and Belém. It is visited by the scarab bectle Cyclocephala castanea Oliv. in the Manaus vicinity and by $\mathrm{C}$. verticalis Burm. in the Belém vicinity. $\mathbf{N}$. rudgeana is protogynous and cross-pollination is quite frequent. N. ampla (Salisb.) DC., a day flowering species, was studied near Salvador, Bahia. This species is visited by the bee species Trigona spinipes. N. ampla is not protogynous and is largely self-fertilized, although a small amount of crossfertilization may occur through the activity of the Trigona bees.
\end{abstract}

\section{INTRODUCTION}

Following the study of the biology of Victoria amazonica (Poepp.) Sowerby made by the senior author (Prance \& Arias, 1975; Prance et al. 1975), we decided to continue the work with other Brazilian species of Nymphaeaceae. The present paper presents the results of our observations on two species of the genus, Nymphaea, with the uitimate aim of providing enough material to discuss evolutionary trends in the family on the basis of floral biology.

\section{Nymphaea rudgeana G.F.W. Meyer}

This species was studied in the vicinity of Manaus and Belém. As the observed species of pollinating beetles were different in the two areas, the results from each area are presented separately.

\section{VICINITY OF MANAUS}

Herbarium Material: Prance \& Ramos 23384, Rio Preto da Eva, Manaus-Itacoatiara road, km 79, Amazonas, Brazil. (INPA, NY); Prance \& Ramos 23521, Manaus-Itacoatiara road, km 89, Amazonas, Brazil (INPA, NY).

\section{STUDY AREA}

In the vicinity of Manaus Nymphaea rudgeana was observed at the two localities cited above, on the Manaus-Itacoatiara road. The Rio Preto site is a natural area where the plant grows in shallow water $(20-100 \mathrm{~cm}$ depth) at the river margin. The $\mathrm{km} 39$ site is an artificial lake caused by the road embankment in an area that was formerly forest on high ground.

Here $N$. rudgeana completely covers the surface of the lake, which has a small stream running through it.

\section{OBSERVATIONS}

$N$. rudgeana is a night flowering species in which the flowers open for two consecutive nights and are visited by the scarab beetle Cyclocephala castanea Oliv. This species of beetle was commonly found in the flowers of Victoria amazonica, see Prance \& Arias (1975), Prance et al. (1975).

The flower opening sequence is given below for one night of observations. The same sequence with minor time differences (depending on cloud cover etc.) was observed on all 10 nights of field work.

The opening of the flowers is directly linked with the onset of darkness as in Victoria amazonica (Gessner, 1960; Prance \& Arias, 1975). All the flowers on the lake open at the same time, as it becomes dark. At that time they are strongly scented with a fruity smell. When the light is still bright in the West the flowers open unilaterally, opening on the shaded (East) side first.

By marking flowers with colored tape we established that they open for two consecutive nights only. On both nights they give off the

(") - The New York Botanical Garden, Bronx, New York, 10458, and Instituto Nacional de Pesquisas da Amazônia, Manaus.

("*) - Instituto Nacional de Pesquisas da Amazônia, Manaus. 
TABLE 1

Flower opening sequence for Nymphaea rudgeana in the vicinity of Manaus

(Manaus-Itacoatiara $\mathrm{km} \mathrm{39)}$

\begin{tabular}{|c|c|c|}
\hline Time & Light & Observations on 25.06 .75 \\
\hline $17: 45$ & Daylight & $\begin{array}{l}\text { All flowers closed, buds with } \\
\text { fruity smell. }\end{array}$ \\
\hline $18: 15$ & Sunset & $\begin{array}{l}\text { Sepals slightly open, strong } \\
\text { fruity small over lake. }\end{array}$ \\
\hline $18: 30$ & $\begin{array}{l}\text { End of } \\
\text { twilight }\end{array}$ & $\begin{array}{l}\text { Sepals more open, white of } \\
\text { petals now showing. }\end{array}$ \\
\hline $18: 45$ & Dark & $\begin{array}{l}\text { Sepals and outer petals reach } \\
45^{\circ} \text { angle, central cone of petals } \\
\text { still closed. }\end{array}$ \\
\hline $18: 55$ & & $\begin{array}{l}\text { First beetle (Ciclocephala cas- } \\
\text { tanea) observed entering a flo- } \\
\text { wer by forcing central cone of } \\
\text { petals open. }\end{array}$ \\
\hline 19:20 & & $\begin{array}{l}\text { Flowers with sepals and outer } \\
\text { petals wide open, sepals at } 75^{\circ} \\
\text { angle, central cone, of petals } \\
\text { closed or slightly open in some } \\
\text { flowers. }\end{array}$ \\
\hline
\end{tabular}

same smell at equal intensity, but only on the second night is the pollen released from the linear anthers. This suggests that the stigma is receptive on the first night. Thus, like Victoria, this species exhibits protogyny.

At both sites studied, the flowers of $N$. rudgeana are visited by the scarab beetle Cyclocephala castanea Oliv. The beetle population was not dense at the time of our study (25 June -17 July): with numerous flowers open (ca 300) on the lake at $\mathrm{km} \mathrm{39}$, we could only find an average of six beetles in any one evening. The beetles appear to come from the surrounding forest shortly after nightfall. Only one beetle at a time was observed in the flowers.

\section{ii. VICINITY OF BELÉM}

Herbarium material: Ancierson 159, small stream near beginning of Estrada Coqueiro, Belém, Pará, Brazil (INPA, NY).

\section{STUDY AREA}

The Belém study area, like one of the Manaus sites, is an artificial lake caused by a road embankment in an area which was former- ly forest. Beyond the lake are areas which are still forest. N. rudgeana forms a dense cover near the margins of the lake in water depths from 1 to 2 meters.

\section{OBSERVATIONS}

As in the Manaus region, flowering is nocturnal and the flowers open for two or three consecutive nights. They are visited by the scarab beetle Cyclocephala verticalis Burm. This is a smaller species of the same genus as the beetle which visits $N$. rudgeana in the vicinity of Manaus. C. verticalis is another species that was found occasionally in the flowers of Victoria amazonica, see Prance \& Arias (1975), Prance et al. (1975).

The sequence of flower opening for two nights at Belém is given below:

TABLE 2

Flower opening sequence for Nymphaea rudgeana in the vicinity of Belém

\begin{tabular}{lll} 
Time & Light & \multicolumn{1}{c}{ Observations on 14.07.75 } \\
\hline 17:45 & Daylight & \multicolumn{1}{c}{ and 16.07.75 } \\
18:15 & Sunset & $\begin{array}{l}\text { Sepals slightly open, strong } \\
\text { fruity smell all over lake. }\end{array}$ \\
18:30 & $\begin{array}{l}\text { End of } \\
\text { twilight }\end{array}$ & $\begin{array}{l}\text { Sepals more open, white of } \\
\text { petals now showing. }\end{array}$ \\
Fruity smell more intense. \\
18:45 & Dark & $\begin{array}{l}\text { Sepals and outer petals wide } \\
\text { open, central cone of petals } \\
\text { closed. }\end{array}$ \\
& & $\begin{array}{l}\text { First beetle (Cyclocephala ver- } \\
\text { ticalis) observed landing on } \\
\text { sepals and entering flower by } \\
\text { forcing open the central cone } \\
\text { of petals. } \\
\text { Central cone of petals slightly } \\
\text { open in some flowers. }\end{array}$ \\
\hline
\end{tabular}

The tables show that the behavior of the flowers is similar at both the Manaus and Belém sites.

By marking the flowers with colored tape we established that they open for either two or three consecutive nights at Belém. By the third or fourth night, the flowers have a rosy pink color and emit no scent. On the first 


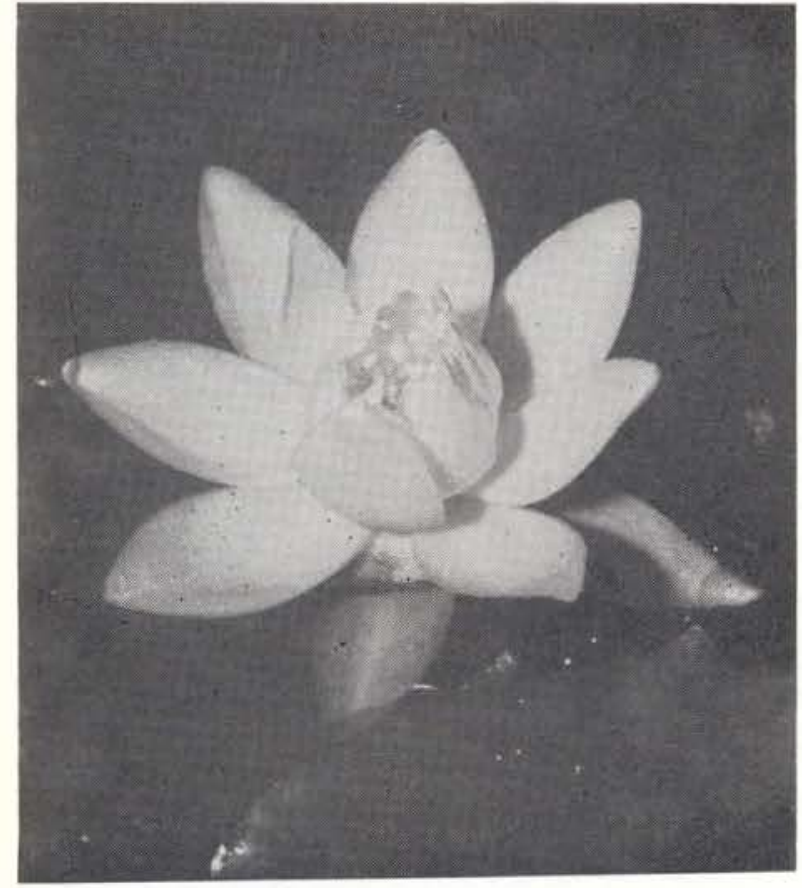

Fig. 1. Open flower of Nymphaea rudgeana.

two or three nights of opening, the flowers give off the same smell at equal intensity, but only on the second and third nights does the pollen appear to be released from the inear anthers. This suggests that the stigma is receptive on the first night. Thus, like $V$. amazonica, this species exhibits protogyny.

The flowers are visited by the scarab beetle Cyclocephala verticalis. The beetle population was not dense at the time of our observations (July $14-16,1975$ ): with numerous flowers open (ca 50), we could only find a maximum of four beetles in any evening. The beetles appear to come from the adjacent forest shortly after nightfall and enter the flowers. They move freely from one flower to another during the night. Usually only one beetle, or at the most two, enter a flower at any one time.

\section{DISCUSSION}

The pollination of Nymphaea rudgeana differs considerably from that of Victoria amazonica. In Victoria, the beetles are trapped inside the flowers during the day. At nightfall, the flowers open and the beetles emerge covered with pollen, whereupon they are attracted to receptive first day flowers, which are white and strongly scented. In Nymphaea ruigeana, the beetles are not trapped inside the flowers during the day, nor is there any change in scent or color between first and second day flowers. In order to effect crosspollination, a beetle must move by chance from a second or third day flower, which is shedding pollen, to a receptive first day flower, and not to another second or third day flower. Furthermore, the relatively small size of the flowers of $N$. rudgeana does not allow for more than one or at the most two beetle visitors at a time; in contrast, the large flowers of Victoria accommodate half a dozen or more beetles at one time. As a result, the pollination mechanism of $N$. rudgeana is far less efficient than that of Victoria. However, a certain amount of gene exchange is ensured within the species. Beetles which visit second day flowers always emerge covered with pollen which sticks to them, and when by chance they visit a first day flower with a receptive stigma, cross-pollination is likely.

In the Manaus area, flowers which were bagged during their three days above water

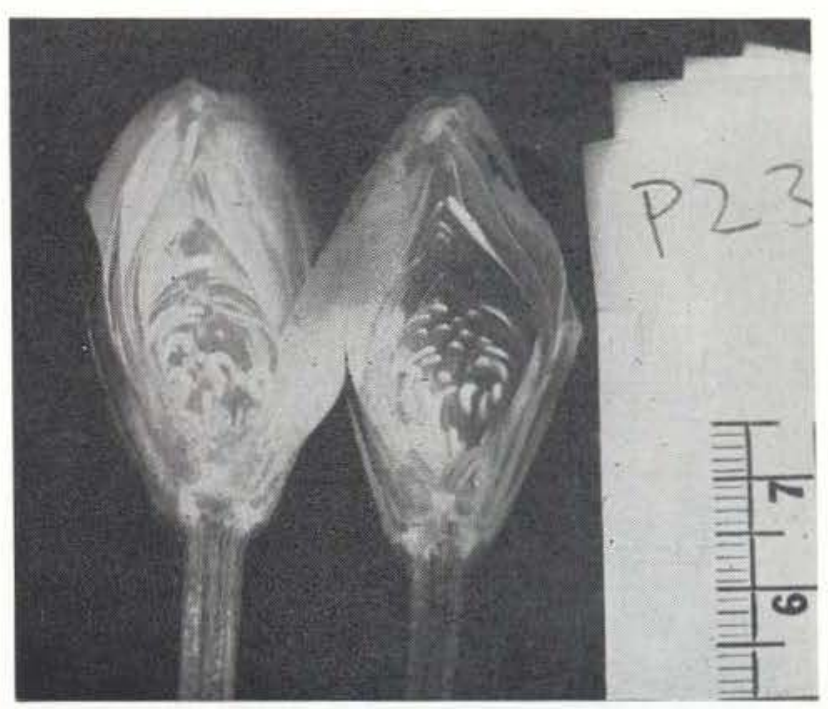

Fig. 2. Flower section of Nymphaea rudgeana, showing the inner recurved staminodes which are eaten by the beetles. 


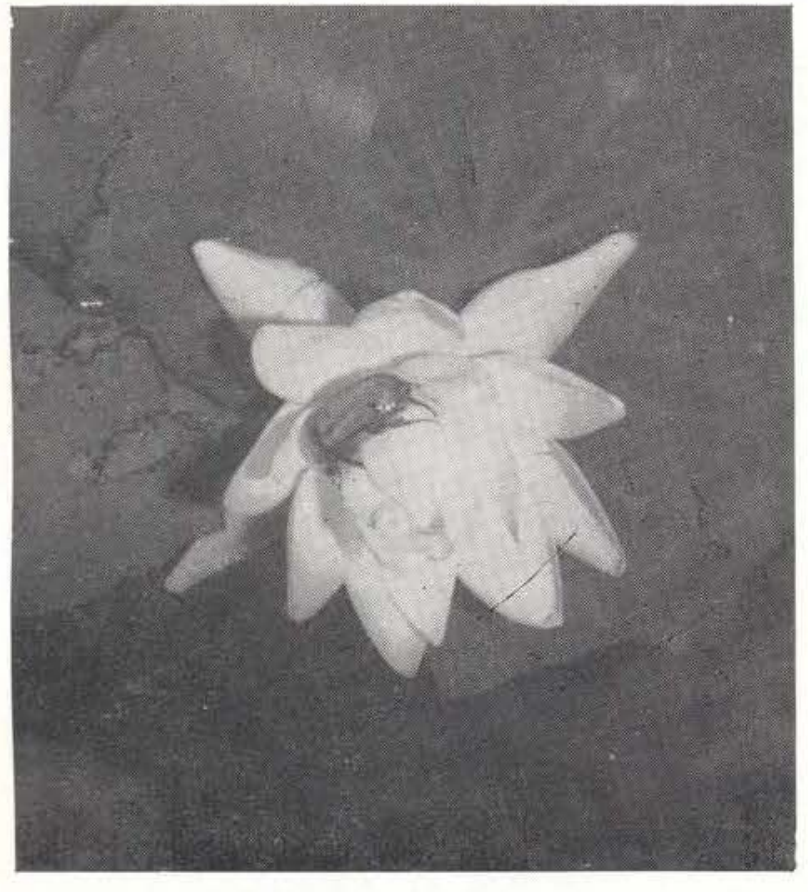

Fig. 3. Flower of Nymphaea rudgeana with the beetle Cyclocephala castanea on the petals.

set seed freely, showing that $N$. rudgeana is self-compatible. It is probable that autogamy is the predominant form of pollination in $N$. rudgeana.

\section{Nymphaea ampla (Salisb.) DC.}

Herbarium material: Anderson 162, Lagoa do Abaeté, approximately $10 \mathrm{~km}$ NE of Salvador. Bahia, Brasil (INPA, NY); Anderson 225, Same locality (INPA, NY).

\section{STUDY AREA}

N. ampla was studied in a natural blackwater lake surrounded by dunes of white sand within a few hundred meters of the ocean. The dunes are covered by a low, dense vegetation known as restinga. $N$. ampla occurs in low concentrations over scattered areas near the margin of the lake, in depths of water from 1-3 meters.

\section{OBSERVATIONS}

$N$. ampla is a dayflowering species which is visited by the bee Trigona (Trigona) spinipes $(=T$. ruficrus $)$. The flowers are white and give off a sweet scent which is not as pungent or fruity as the flowers of $N$. rudgeana. In N. ampla, the flowers open for three to four consecutive days, whereupon they sink beneath the surface of the lake. The species was observed in flower during July (1975) and January (1976).

TABLE 3

Flower opening sequence for Nymphaea ampla in the vicinity of Salvador

\begin{tabular}{lll}
\hline Time Light & \multicolumn{1}{c}{ Observations on 13.01.76 } \\
\hline 5:00 & Twilight & All flowers closed. \\
5:45 & Sunrise & \\
6:00 & Full daylight & \\
$7: 00$ & & Sepals of some flowers begin \\
& to open, slight scent emitted \\
& from flowers. \\
7:15 & Some flowers with sepals and \\
& petals wide open, others with \\
& sepals beginning to open; all \\
& flowers emitting slight scent. \\
& Arrival of first bees, which \\
& enter open flowers and land \\
& on closed flowers, chewing the \\
& tips of the closed petals. \\
8:00 & All flowers open. Bee activity \\
& intense. \\
$10: 00$ & Bee activity declining. \\
$12: 00$ & Very few bees in vicinity of \\
$15: 00$ & flowers. \\
$17: 00$ & Flowers begin to close. \\
$18: 15$ Sunset & All flowers closed. \\
& & \\
\hline
\end{tabular}

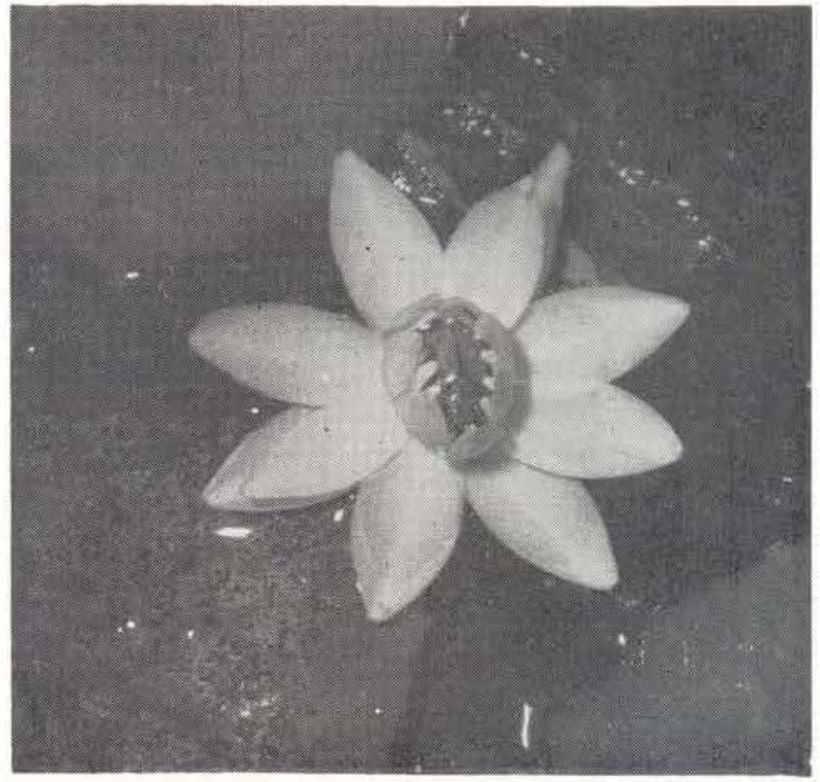

Fig. 4. Flower of Nymphaea rudgeana with the beetle Cyclocephala castanea inside the flower among the stamens. 


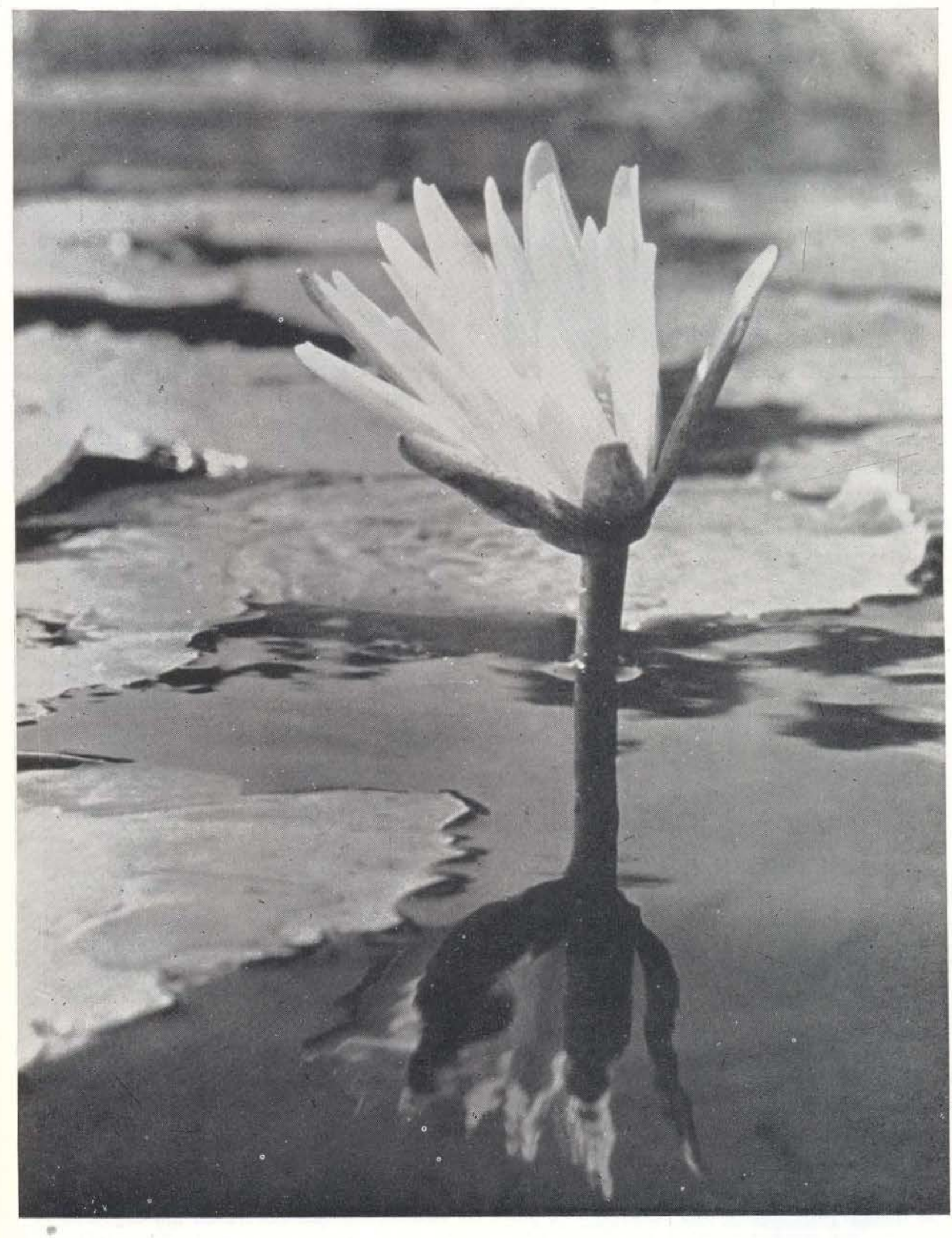

Fig. 5. Flower of Nymphaea ampla. 


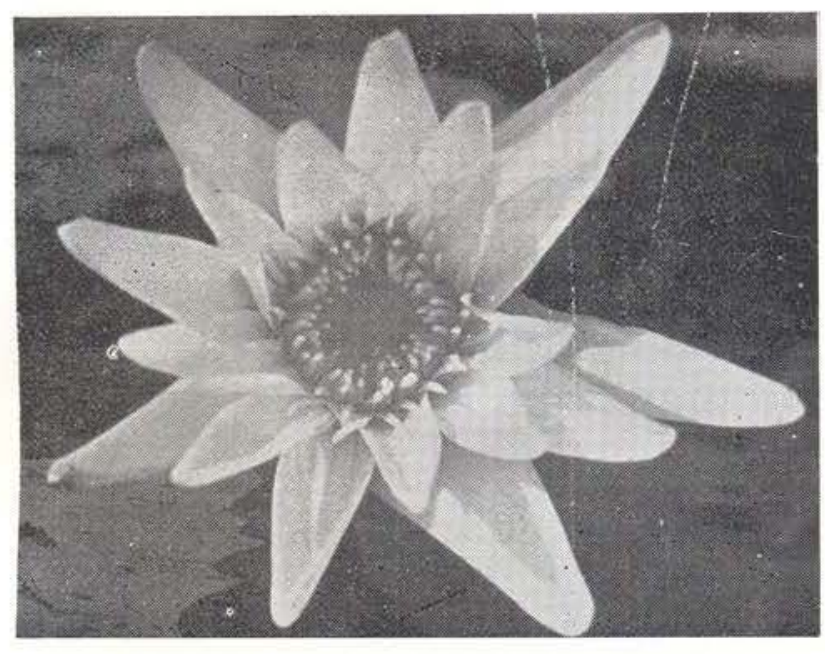

Fig. 6. Flower of Nymphaea ampla.

The flower opening sequence is given above for one day of observations. The same essential sequence was observed during the entire 3 days of field work.

The opening of the flowers does not appear to be directly linked with the approach of daylight. Nor is the timing of flower opening as synchronized among the population as it is, for example, in populations of $N$. rudgeana. It is possible that temperature is a more effective cue than sunlight for the opening and closing of the flowers in this species.

By marking the sepals of the flowers with indelible ink, we determined that they open for three to four consecutive days. By the third or fourth day the flowers have a rosy pink color and emit no scent. On the first two oi three days of opening, the flowers give off the same delicate scent at equal intensity. The flowers generally appear on the surface of the lake a full day prior to their initial opening. Examination of these unopened flowers showed that pollen had already been released from the anthers and had fallen onto the stigmatic area, which was still moist with lake water. The stamens were observed to be continually fertile throughout the flowering period, releasing copious amounts of pollen, much of which falls onto the stigmatic area. By the second or third day, the moisture on the stigmatic area has completely evaporated, which sug- gests that the flowers may only be receptive on the first day.

The flowers are visited by the bee Trigona (Trigona) spinipes ( $=T$. ruficrus). During the three mornings of observations, as many as 9 bees could be seen visiting the 30 o: more opened flowers in one area of the lake. The bees arrive at the time that the flowers are just beginning to open. They land on the first, second or even third day flowers and begin to chew the upper tips of the closed petals in an apparent attempt to gain entry. f:s these bees are extremely slow and sporadic workers, they probably would never penetrate the thick cone of petals on their own if the flowers did not then commence to open, thus allowing the bees to enter inside. Once inside, the bees begin to collect pollen from the inner rows of fertile stamens, which are curled over the sigmatic area. During this process, considerable amounts of pollen fall from the anthers onto the stigmatic area. One bee was observed visiting a single flower for 17 minutes, during which time it caused far greater quantities of pollen to spill from the stamens onto the stigmatic area than it collected. The bees generally emerge from the flowers covered with pollen, which sticks to them. No other insects were observed actualiy entering the flowers.

\section{DISCUSSION}

The Trigona bees are probably responsible for a small amount of out-crossing in $N$. ampla. The bees emerge from each flower covered with pollen, and visits to adjacent flowers enable cross-pollination to occur. However, the amount of pollen transfer effected by bees is minimal compared to the large quantities of pollen which spill from the anthers onto the stigmatic area throughout the flowering period

The small amount of pollen transfer effected by the bees cannot account for the abundance of capsules bearing apparently viable seeds which were found in the areas where N. ampla occurs on the Lagoa de Abaeté. No mechanisms such as protogyny (observed in $N$. rudgeana) or protandry occur in this species. Furthermore, no chemical or other 
barriers to self-pollination have been reported in other species of Nymphaeaceae. Therefore, it seems safe to conclude that autogamy is the predominant form of pollination in $N$. ampla, with occasional outcrossing effected by Trigona bees.

Nymphaea ampla, ranging from Texas to central Brazil, is one of the most widespread American species of its genus. The species is predominantly autogamous in the area studied, which is at the extreme southern part of its range. It is likely that the autogamous reproduction system enables this species to spread beyond the range of its normal pol!inators. The importance of autogamy in the migration of species is well-known, and has been much commented upon especially in relation to island species.

\section{ConClusions}

The two species studied belong to different sections of Nymphaea and have completely different floral biology. $N$. rudgeana belongs to sections Syncarpiae of Conard (1905) and N. ampla to section Apocarpiae. These sections differ in the amount of fusion of the carpels: in section Syncarpiae, the carpels are completely fused, while in Apocarpiae the upper part of the carpels is free. The evolution of the carpel of Nymphaea was discussed in some detail by Moseley (1961), based on vascular anatomy and ontogony. He outlines the two trends to complete fusion of the carpels or to fusion on the lower portion only, but he does not derive the Syncarpiae from the Apocarpiae. In at least the two species studied here, the member of Syncarpiae, N. rudgeana, is night flowering and beetle pollinated, and the Apocarpiae, N. ampla, is day flowering, visited by bees, but largely autogamous. Further studies of other species are necessary to determine whether any correlation exists between carpel type and pollination or fertilization system.

Our studies to date of floral biology in the Nymphaeaceae suggest that there exists a correlation between the length of time that flowers remain open and the effectiveness of outcrossing. For example, in Nymphaea ampla flowers remain open for 3-4 days and, as we have shown, outcrossing is rare and fertilization occurs predominantly via autogamy. In $N$. rudgeana, flowers remain open for shorter periods (2-3 days) and outcrossing appears to be more frequent, although autogamy remains predominant. Finally, in Victoria amazonica, the period of flower opening is the least extensive ( 1 day) and fertilization occurs predominantly via outcrossing. In summary, $V$. amazonica, with its extremely effective cross. pollination system, achieves outcrossing in a minimal period of time; by contrast, the species with less effective cross-pollination systems, $N$. rudgeana and $N$. ampla, maintain their flowers open for longer periods, apparently thereby increasing the probability of a certain amount of outcrossing. Further stucies of floral biology in other species of Nymphaea. ceae would reveal whether there is a general correlation between the length of time that flowers remain open and the effectiveness of outcrossing. Such a correlation may prove to have evolutionary sigrificance within the family.

\section{ACKNOWLEDGEMENTS}

The fieldwork was supported by the insti. tuto Nacional de Pesquisas da Amazônia, Manaus, and by the National Science Foundation Grant GB-32575 $\times 3$, and the work was carried out while the junior author held a Thomas J. Watson Fellowship: all are gratefully acknowledged. We thank José F. Ramos and Elza Suely Anderson for help with the fieid work, Prof. Dr. Warwick E. Kerr for identification of the bees, and Dr. Sebo Endrödi for identificetion of the beetles.

\section{Resumo}

Foi feito um estudo da biologia floral de duas espécies do gênero Nymphaea (Nymphaeaceae). N. rudgeana G.F.W. Meyer floresce durante a noite e foi estudada perto de Manaus e Belém. Na vizinhança de Manaus foi encontrada a espécie de besouro Cyclocephala castanea Oliv. (Scarabaeidae: Dynastinae) nas flores de $\mathbf{N}$. rudgeana, porém na 
vizinhança de Belém foi encontrada outra espécie de besouro, Cyclocephala verticalis Burm. N. rudgeana é protogínica e polinização cruzada é frequiente. Nymphaea ampla (Salisb.) DC. floresce durante o dia e foi estudada perto de Salvador, Bahia. Nesta espécie foram encontradas abelhas Trigona, T. spinipes. N. ampla não é protogínica e é predominantemente autogama, porém um pouco de polinização cruzada pode acontecer devido a atividade das abelhas.

\section{LITERATURE CITED}

CONRAD, H. S.

1905 - The water lilies. A monograph of the genus Nymphaea. Carnegie Inst. Was. hington Publ., 4.
GESSNER, F.

1962 - A abertura das flores de Victoria regia em relação a luz. Bol. Mus. Goeldi, N. Sér. Botânica $17: 1$-13.

Moseley, M. F.

1961 - Morphological studies of the Nymphaeaceae II. The Flower of Nymphaea. Bot Gaz., $122:$ 233-259.

Prance, G. T. \& J. R. ARIAS

1975 - A study of the Floral Biology of Victoria amazonica (Poepp.) Sowerby (Nymphaeaceae). Acta Amazonica, 5 (2) : 109-139.

Prance, G.T., Prance, A.E. \& J.R. Arias

1975 - A biologia floral de Victoria amazonica (Poepp.) Sowerby (Nymphaeaceae) Ciência e Cultura, 27: 1293-1297.

\section{NOTE}

While this article was in press, we received a paper on Nymphaea spp. in Surinam. (Cramer, J. M., A.D.J. Meeuse \& P.A. Teunissen (1975): A note on the pollination of nocturnally flowering species of Nymphaea. Acta Bot. Neerl. $24: 489-490$ ).

In Surinam, Nymphaea blanda var. fenzliana is nocturnally flowering and visited by beetles (Cyclocephala castanea); its odor is "sweet and fruity but with a pungent, phenolic admixture ('like xylene')." In Bahia, Brazil, N. blanda is diurnal and visited by bees; it emits a sweet, delicate scent that is neither pungent nor fruity. Field evidence suggests that the $\mathbf{N}$. blanda reported by us and the $\mathbf{N}$. blanda var. fenzliana reported by Cramer et al. (1975) may, in fact, represent different species.

In Surinam, N. rudgeana is visited by Cyclocephala castanea and "not infrequently" by C. verticalis as well. Our observations in Amazônia essentially agree: N. rudgeana is visited by C. castanea in the Manaus vinicity and by $\mathbf{C}$. verticalis near Belém. Apparently these two beetle species have considerable overlap in their niches, as both are also reported by Prance \& Arias (1975) to be secondary visitors of Victoria amazonica near Manaus. However, V. amazonica is predominantly pollinated by C. hardyi Endröni (Prance \& Arias, 1975), a coleopteron not observed visiting Nymphaea spp. in Amazônia nor in Surinam. As Cramer et al. (1975) suggest, C. hardyi exhibits a clear-cut niche differentiation.

Cramer et al. (1975) propose that the pollination system of the two Nymphaea species is very much the same as in V. amazonica. However, our observations reveal important differences. The pollination system of $v$. amazonica an increase in temperature within the flowers, a short flowering period (1 day), and a high degree of outcrossing. Conversely, the pollination system of $\mathbf{N}$. rudgeana is far less sophisticated: temperature increases were not observed in the flowers, flowering periods are relatively long (2-3 days), and outcrossing is much less common. Our study of floral biology in species of Nymphaea supports the conclusion that the pollination system of $\mathbf{V}$. amazonica represents a highly evolved and specialized development within the Nymphaeaceae. 